\title{
Maternal Age at Delivery and Enzyme Polymorphisms in Children with Type 1 Diabetes Mellitus
}

\author{
Fulvia Gloria-Bottini ${ }^{1}$ Anna Neri ${ }^{1}$ Patrizia Saccucci ${ }^{1}$ Maria Luisa Manca Bitti ${ }^{2}$ Novella Rapini ${ }^{2}$ \\ Gabriele Renzetti ${ }^{1}$ Andrea Magrini ${ }^{1}$ Egidio Bottini ${ }^{1}$
}

${ }^{1}$ Department of Biomedicine and Prevention, University of Rome Tor Vergata, Rome, Italy

2 Department of Medical Science, Pediatric Diabetes Unit, University of Rome Tor Vergata, Rome, Italy

Address for correspondence Fulvia Gloria-Bottini, MD, Department of Biomedicine and Prevention, University of Rome Tor Vergata, Via Montpellier 1, 00133 Rome, Italy (e-mail: gloria@med.uniroma2.it).

J Child Sci 2018;8:e7-e10.

\begin{abstract}
Keywords

- $\mathrm{ACP}_{1}$

- maternal age

- p53 codon 72

- PTPN22

- type 1 diabetes mellitus

Fetal genetic adaptation to environment of aging women could result in positive selection of genes that during extrauterine life increases the risk of type 1 diabetes mellitus (T1DM). We have examined the distribution of three genetic polymorphisms (acid phosphatase locus $1\left[\mathrm{ACP}_{1}\right]$, p53 codon 72, and PTPN22) involved in T1DM risk in relation to maternal age at delivery. p53 codon 72 was determined in 281 T1DM children, $\mathrm{ACP}_{1}$ in 207 children, and PTPN22 in 216 children. Controls (blood donors) were 351 for $\mathrm{ACP}_{1}, 271$ for PTPN22, and 730 for $\mathrm{p} 53$ codon 72 . Genotypes were determined by DNA analysis. The proportions of the three genotypes associated with T1DM are much greater in T1DM children from older mothers than in those from young mothers and in controls. The data support the hypothesis that advanced maternal age favors a positive selection of genes more adapted to the uterine environment of older women: these genes predispose to T1DM during extrauterine life.
\end{abstract}

\section{Introduction}

The frequency of type 1 diabetes mellitus (T1DM) increases with maternal age at conception. ${ }^{1-5}$ High pregnancy estrogen concentration in older women may have an important role; however, the mechanism of the association between T1DM and maternal age is unknown. ${ }^{6}$

Experimental data and clinical observations suggest that delaying childbearing influences the biology of the motherfetus relationship. ${ }^{7,8}$ Advanced maternal age could influence intrauterine selection favoring genotype more adapted to the environment of less young women. Indeed, we have found that advanced maternal age is associated with changes in the frequency of haptoglobin phenotypes in the mother and with changes of $\mathrm{PGM}_{1} / \mathrm{RhC}$ haplotype distribution in both mothers and offspring. ${ }^{9}$

Thus, we reasoned that fetal genetic adaptation to the environment of aging women could result in a positive selection of genes that during extrauterine life may increase the risk of immunological diseases such as T1DM.

received

April 28, 2017

accepted after revision

January 11, 2018
In the present note, we have examined the distribution of three genetic polymorphisms involved in T1DM risk (acid Phosphatase Locus 1 ACP $_{1}$ ], p53 codon 72, and PTPN22) ${ }^{10-12}$ in children with T1DM in relation to maternal age at delivery.

\section{Acid Phosphatase Locus 1}

Cytosolic low molecular weight protein tyrosine phosphatase (cLMWPTP) is encoded by $\mathrm{ACP}_{1}$ gene that shows three codominant alleles: $\mathrm{ACP}_{1}{ }^{*} \mathrm{~A}, \mathrm{ACP}_{1}{ }^{*} \mathrm{~B}$, and $\mathrm{ACP}_{1}{ }^{*} \mathrm{C}$ and correspondingly six genotypes with enzymatic activity increasing in the order ${ }^{*} \mathrm{~A} /{ }^{*} \mathrm{~A}<{ }^{*} \mathrm{~A} /{ }^{*} \mathrm{~B}<\left({ }^{*} \mathrm{~B} /{ }^{*} \mathrm{~B} \leq{ }^{*} \mathrm{~A} /{ }^{*} \mathrm{C}\right)<{ }^{*} \mathrm{~B} /{ }^{*} \mathrm{C}<{ }^{*} \mathrm{C} /{ }^{*} \mathrm{C}$. ${ }^{13,14}$

cLMWPTP is able to dephosphorylate a negative phosphorylation site in the ZAP70 tyrosine kinase in T cell, ${ }^{15}$ and as consequence of the increase of $\mathrm{ACP}_{1}$ activity, there is an increase in ZAP70 activity and signaling from $\mathrm{T}$ cell antigen receptor.

\section{p53 Codon 72}

p53 codon 72 shows a polymorphism due to a single nucleotide substitution that changes arginine to proline in the
DOI https://doi.org/ 10.1055/s-0038-1636930. ISSN 2474-5871.
Copyright (c) 2018 Georg Thieme Verlag License terms KG Stuttgart · New York

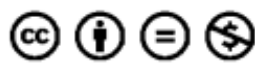


protein. There are three genotypes *Arg/*Arg, *Arg/*Pro, and ${ }^{*}$ Pro/*Pro. The arginine variant induces a strong apoptosis activity, while Proline variant induces a strong transcriptional activity. ${ }^{16}$

p53 is involved in autoimmune diabetes through downregulation of STAT1. ${ }^{17}$

\section{PTPN22}

Human lymphoid tyrosine phosphatase (Lyp) is encoded by PTPN22 gene and is a regulator of signaling through $T$ cell receptor. The polymorphism is due to a substitution of an arginine with a tryptophan at codon 620 . The substitution generates the Lyp-W620 variant that is associated with autoimmune disorders and gain of function of the enzyme. $^{12-18}$

The polymorphism has two alleles ${ }^{*} \mathrm{C}$ (R-620 variant) and ${ }^{*} \mathrm{~T}$ (W-620 variant) and three genotypes ${ }^{*} \mathrm{C} /{ }^{*} \mathrm{C},{ }^{*} \mathrm{C} /{ }^{*} \mathrm{~T}$, and ${ }^{*} \mathrm{~T} /{ }^{*} \mathrm{~T}$.

\section{Materials and Methods}

We have studied 281 children with T1DM from the white population of Rome: p53 codon 72 was determined in all subjects, $\mathrm{ACP}_{1}$ in 207, and PTPN22 in 216 subjects. Controls (blood donors) from the same population were 351 for $\mathrm{ACP}_{1}, 271$ for PTPN22, and 730 for $\mathrm{p} 53$ codon 72 . Maternal age at delivery had been registered in clinical records in 90 mothers. These subjects have also been considered in previous studies. ${ }^{9,11}$

Genotype of $\mathrm{ACP}_{1}$, PTPN22, and p53 codon 72 was determined by DNA analysis as previously described. ${ }^{19}$

\section{$\mathrm{ACP}_{\mathbf{1}}$}

Total genomic DNA was extracted from frozen whole blood samples collected in ethylenediaminetetraacetic acid. The amplification conditions consisted of an initial denaturation at $94^{\circ} \mathrm{C}$ for 2 minutes, followed by 35 cycles of $94^{\circ} \mathrm{C}$ for 45 seconds, $54^{\circ} \mathrm{C}$ for 45 seconds, $72^{\circ} \mathrm{C}$ for 45 seconds, and a final extension of $72^{\circ} \mathrm{C}$ for 5 minutes.

Ten microliters of the 341-bp exon 3 amplicon was fully cleaved by $\mathrm{Cfol}$ at $37^{\circ} \mathrm{C}$ for 1 hour according to the manufacturer's instructions and then electrophoresed on $1.8 \%$ agarose gels. The digestion created two fragments of 255and 86-bp for $\mathrm{ACP}_{1}{ }^{*} \mathrm{~A}$ and $\mathrm{ACP}_{1}{ }^{*} \mathrm{~B}$ alleles, while the $\mathrm{ACP}_{1}{ }^{*} \mathrm{C}$ allele was not out. Similarly, the 299-bp polymerase chain reaction (PCR) product was digested by Taq 1 at $65^{\circ} \mathrm{C}$ for 1 hour according to the manufacturer's instructions, generating two fragments of 100 and $199 \mathrm{bp}$ for the $\mathrm{ACP}_{1}{ }^{*} \mathrm{~A}$ allele but not for the ${ }^{*} \mathrm{~B}$ and ${ }^{*} \mathrm{C}$ alleles.

\section{PTPN22}

A DNA fragment was amplified by PCR in a $25 \mu \mathrm{L}$ totalvolume reaction, containing $100 \mathrm{ng}$ of genomic DNA, $2.5 \mathrm{nM}$ of $\mathrm{MgCl}_{2}, 1 \times$ buffer Gold (Applied Biosystems, Foster City, California, United States), $10 \mathrm{pmol}$ of each primer, $0.2 \mathrm{mM}$ of deoxyribonucleotide triphosphate, and $0.5 \mathrm{U}$ of Amplitaq Gold (Applied Biosystems). Thirty cycles $\left(30 \mathrm{~s}\right.$ at $95^{\circ} \mathrm{C}, 30 \mathrm{~s}$ at $60^{\circ} \mathrm{C}$, and $30 \mathrm{~s}$ at $72^{\circ} \mathrm{C}$ ) were performed with the DNA thermal cycler (Perkin Elmer).
The $\mathrm{C} / \mathrm{T}$ transition at codon 620 (NCBI refSNP ID: rs2476601) creates a $\mathrm{Xcml}$ restriction site in the ${ }^{*} \mathrm{~T}$ allele. The polymorphism was identified by $\mathrm{Xcml}$ restriction endonuclease (NEB, Beverly, Massachusetts, United States) digestion of the polymerase chain reaction amplified fragment. After electrophoresis, the gel was stained with ethidium bromide, and the fragments were visualized under ultraviolet light.

\section{p53 Codon 72}

Polymerase chain reactions were performed in a total volume of $25 \mu \mathrm{L}$ containing $200 \mathrm{ng}$ of genomic DNA, 0.4 pmol of each primer, $2 \mathrm{mmol} / \mathrm{L}$ of $\mathrm{MgCl}_{2}, 200 \mathrm{mmol} / \mathrm{L}$ of deoxynucleotide triphosphates, $1 \times$ buffer, and $2 \mathrm{U}$ of Taq polymerase. The amplification was performed for 35 cycles with an annealing temperature of $62^{\circ} \mathrm{C}$. The amplified DNA was digested for 3 hours with $3 \mathrm{U}$ of AccII restriction enzyme. The DNA fragments were resolved by electrophoresis on a $3 \%$ agarose gel.

Informed consent was obtained by the mothers to participate in the research project that was approved by the Council of Department.

Chi-square test of independence and principal component analysis were performed by commercial software (SPSS). The median value of mothers' age was 32 years.

Controls were compared with the whole sample of T1D children and with T1D children from mothers aging 32 years or more at delivery.

\section{Results}

- Table 1 shows the distribution of $\mathrm{ACP}_{1}, \mathrm{p} 53$ codon 72, and PTPN22 genotypes in relation to maternal age at delivery of children with T1DM. As previously described, the proportions of $\mathrm{ACP}_{1}{ }^{*} \mathrm{~A} /{ }^{*} \mathrm{~B},{ }^{*} \mathrm{Arg} /{ }^{*} \mathrm{Arg}$, p53 codon 72 , and carriers of ${ }^{*} \mathrm{~T}$ allele of PTPN22 are greater in subjects with T1DM than in controls. The proportion of these genotypes, however, is much greater in children with T1DM from mothers aging more than 32 years (median value of mothers' age) at delivery. These results suggest that in the environment of aging mothers, zygotes carrying these genotypes could be advantaged with respect to zygotes carrying others genotypes.

-Figs. 1 to 3 show the correlation between maternal age and the proportion of ${ }^{*} \mathrm{Arg} /{ }^{*} \mathrm{Arg}$ genotype, ${ }^{*} \mathrm{~A} /{ }^{*} \mathrm{~B}$ genotype, and carriers of W620 variant of PTPN22 in children with T1DM. A principal component analysis has shown a clear correlation of maternal age with the first two variables and a moderate correlation of maternal age with PTPN22 genotype of children (data not shown).

-Fig. 4 shows the correlation between maternal age and the mean percentage increase in the frequencies of ${ }^{*} A /{ }^{*} B$ genotype, ${ }^{*} \mathrm{Arg} /{ }^{*} \mathrm{Arg}$ genotype, and carriers of ${ }^{*} \mathrm{~T}$ allele in children with T1DM as compared with the frequencies in the general population. With the increase in maternal age, there is a progressive increase in these genotypes compared with the frequencies observed in the general population.

- Table 2 shows the distribution of $\mathrm{ACP}_{1}{ }^{*} \mathrm{~A} /{ }^{*} \mathrm{~B}$ genotype in healthy newborns in relation to maternal age. In the 
Table 1 Distribution of genetic polymorphisms associated with T1DM in relation to maternal age at conception

\begin{tabular}{|c|c|c|c|c|c|c|c|c|c|}
\hline \multirow[b]{2}{*}{ Genetic polymorphisms } & \multirow[b]{2}{*}{ Genotype } & \multicolumn{2}{|c|}{$\begin{array}{l}\text { Controls } \\
\text { (A) }\end{array}$} & \multicolumn{2}{|c|}{$\begin{array}{l}\text { T1DM (all } \\
\text { subjects) } \\
\text { (B) }\end{array}$} & \multicolumn{2}{|c|}{$\begin{array}{l}\text { T1DM } \\
\text { (mothers } \\
>32 \text { y at } \\
\text { conception) } \\
\text { (C) }\end{array}$} & \multicolumn{2}{|c|}{ Comparisons } \\
\hline & & $\%$ & $N$ & $\%$ & $N$ & $\%$ & $N$ & A vs. B & A vs. C \\
\hline $\mathrm{ACP}_{1}$ & ${ }^{*} \mathrm{~A} /{ }^{*} \mathrm{~B}$ & $34.5 \%$ & 351 & $43.5 \%$ & 207 & $57.1 \%$ & 28 & $p=0.035$ & $p=0.020$ \\
\hline p53 codon 72 & ${ }^{*} \operatorname{Arg} /{ }^{*} \operatorname{Arg}$ & $48.8 \%$ & 730 & $58.0 \%$ & 281 & $75.0 \%$ & 28 & $p=0.009$ & $p=0.006$ \\
\hline PTPN22 & ${ }^{*} \mathrm{~T}$ allele carriers & $5.9 \%$ & 271 & $11.6 \%$ & 216 & $17.2 \%$ & 29 & $p=0.030$ & $p=0.027$ \\
\hline
\end{tabular}

Abbreviations: $\mathrm{ACP}_{1}$, acid phosphatase locus 1; T1DM, type 1 diabetes mellitus.

offspring of mothers aging at delivery more than 32 years, there is a statistically significant increase in this genotype, suggesting that the increase in ${ }^{*} \mathrm{~A} /{ }^{*} \mathrm{~B}$ genotype observed in T1DM offspring of older mothers is a general phenomenon

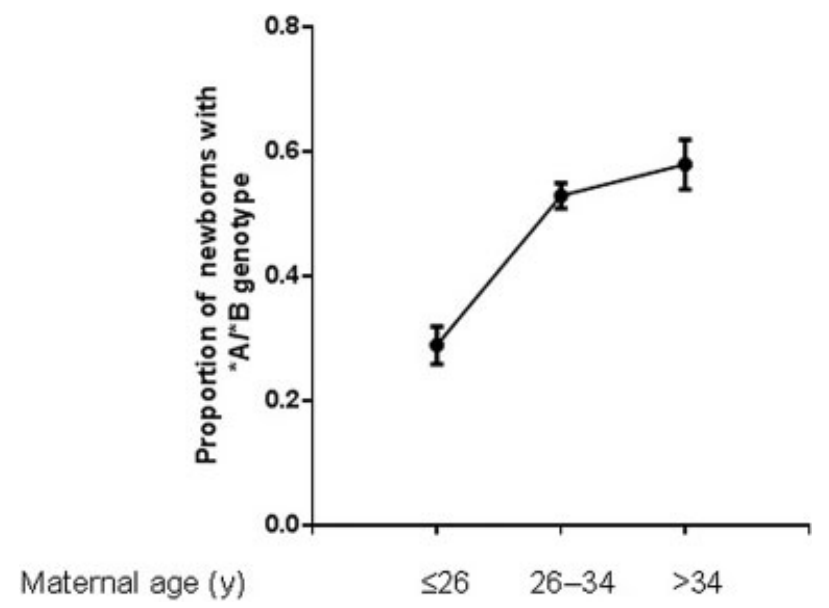

Fig. 1 The correlation between maternal age at birth and the proportion of offspring with T1D carrying the *Arg/*Arg genotype. T1D, type 1 diabetes mellitus.

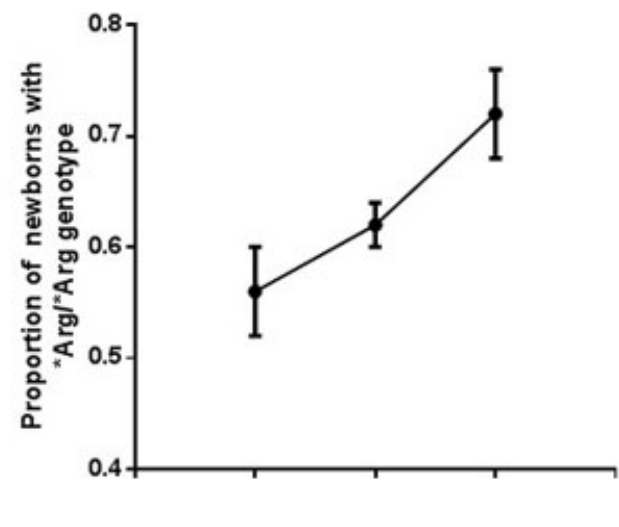

\section{Maternal age $(y) \quad \leq 26 \quad 26-34 \quad>34$}

Fig. 2 The correlation between maternal age at delivery and the proportion of offspring with T1D carrying the ${ }^{*} A /{ }^{*} B$ genotype. T1D, type 1 diabetes mellitus. connected with maternal aging. Unfortunately, we have no similar samples of newborns to study this phenomenon for ${ }^{*} \operatorname{Arg} /{ }^{*} \operatorname{Arg}$ of p53 codon 72 and for carriers for ${ }^{*} \mathrm{~T}$ allele of PTPN22.

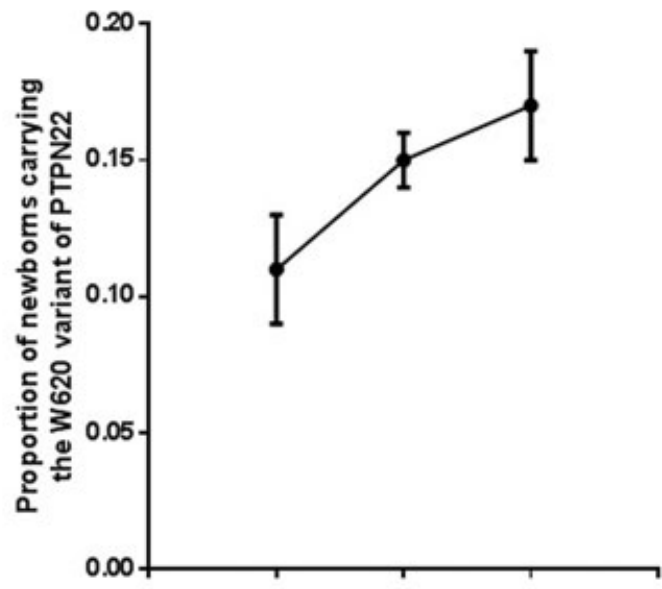

Maternal age $(y) \quad \leq 26 \quad 26-34 \quad>34$

Fig. 3 The correlation between maternal age at delivery and the proportion of offspring with T1D carrying the W620 variant of PTPN22. T1D, type 1 diabetes mellitus.

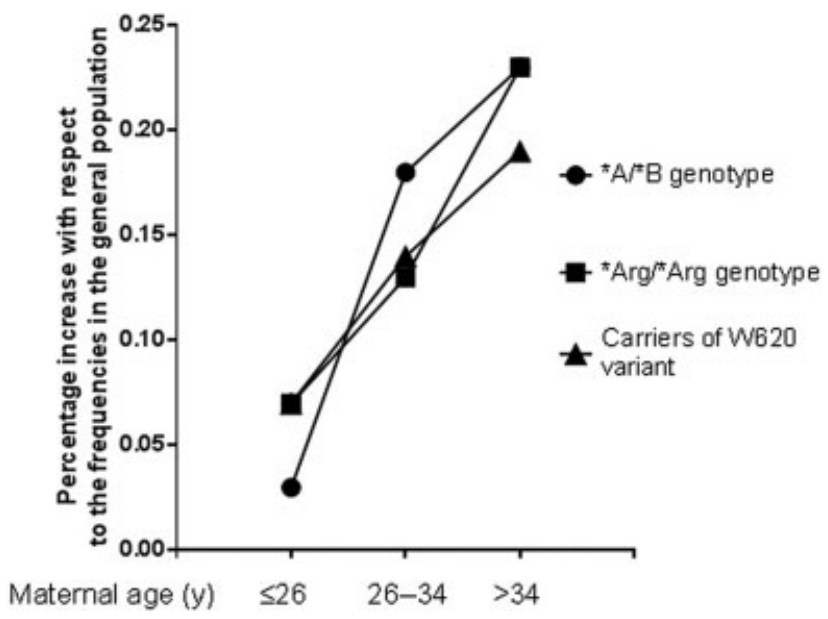

Fig. 4 Correlation between maternal age and percentage increase in the frequencies of ${ }^{*} \mathrm{~A} /{ }^{*} \mathrm{~B}$ genotype, ${ }^{*} \mathrm{Arg} /{ }^{*} \mathrm{Arg}$ genotype, and carrier of W620 variant in T1D children with respect to the frequencies in the general population. T1D, type 1 diabetes mellitus. 
Table 2 Distribution of $\mathrm{ACP}_{1}{ }^{*} \mathrm{~A} /{ }^{*} \mathrm{~B}$ genotype in healthy newborn in relation to maternal age

\begin{tabular}{|l|l|l|l|l|l|}
\hline \multirow{2}{*}{} & \multicolumn{2}{|l|}{$\begin{array}{l}\text { Maternal age } \\
\leq 32 \mathrm{y}\end{array}$} & \multicolumn{2}{l|}{$\begin{array}{l}\text { Maternal age } \\
>32 \mathrm{y}\end{array}$} & \multirow{2}{*}{ Significance of difference } \\
\cline { 2 - 6 } & $\%$ & $N$ & $\%$ & $N$ & \\
\hline \% proportion of *A/*B genotype & $31.3 \%$ & 262 & $43.7 \%$ & 87 & $p=0.042$ \\
\hline
\end{tabular}

Abbreviation: $\mathrm{ACP}_{1}$, acid phosphatase locus 1 .

\section{Discussion}

We have considered three genetic systems involved in immunological functions and associated with T1DM. The analysis of genotype distributions of these systems has shown that in children from mothers aging more than 32 years at delivery, there is a strong increase in genotypes associated positively with T1DM. For $\mathrm{ACP}_{1}$, this increase has been observed also in healthy consecutive newborns delivered by mothers aging more than 32 years.

These data are in favor of the hypothesis that advanced maternal age influences intrauterine selection in favor of genes more adapted to the environment of older women. These genes could favor survival during intrauterine life but predispose to T1DM during extrauterine life.

Several mechanisms have been proposed to explain the association between maternal age and risk to T1DM in the offspring. As far as we know, however, our observation suggests a new mechanism connecting maternal age and susceptibility toT1DM: modification of intrauterine environment due to advancing maternal age favors the survival of fetus carrying genes that predispose to T1DM during extrauterine life.

Further studies on this problem would be rewarding.

\section{Conflict of Interest}

None.

\section{References}

1 Flood TM, Brink SJ, Gleason RE. Increased incidence of type I diabetes in children of older mothers. Diabetes Care 1982;5(06): 571-573

2 Tuvemo T, Dahlquist G, Frisk G, et al. The Swedish childhood diabetes study III: IgM against coxsackie B viruses in newly diagnosed type 1 (insulin-dependent) diabetic children-o evidence of increased antibody frequency. Diabetologia 1989;32 (10):745-747

3 Bingley PJ, Douek IF, Rogers CA, Gale EA; Bart's-Oxford Family Study Group. Influence of maternal age at delivery and birth order on risk of type 1 diabetes in childhood: prospective population based family study. BMJ 2000;321(7258):420-424

4 Bottini N, Meloni GF, Lucarelli P, et al. Risk of type 1 diabetes in childhood and maternal age at delivery, interaction with ACP1 and sex. Diabetes Metab Res Rev 2005;21(04):353-358
5 Gloria-Bottini F, Saccucci P, Meloni GF, et al. Study of factors influencing susceptibility and age at onset of type 1 diabetes: a review of data from Continental Italy and Sardinia. World J Diabetes 2014;5(04):557-561

6 Stene LC, Magnus P, Lie RT, Søvik O, Joner G. Maternal and paternal age at delivery, birth order, and risk of childhood onset type 1 diabetes: population based cohort study. BMJ 2001;323(7309): 369-379

7 Wang $\mathrm{MH}$, vom Saal FS. Maternal age and traits in offspring. Nature 2000;407(6803):469-470

8 Bottini E, Meloni GF, MacMurray J, Ammendola M, Meloni T, Gloria-Bottini G. Maternal age and traits of offspring in humans. Placenta 2001;22(8-9):787-789

9 Gloria-Bottini E, Cosmi E, Nicotra M, Cosmi EV, Bottini E. Is delayed childbearing changing gene frequencies in Western populations? Hum Biol 2005;77(04):433-441

10 Saccucci P, Manca Bitti ML, Bottini N, et al. Type 1 diabetes: evidence of interaction between ACP1 and ADA1 gene polymorphisms. Med Sci Monit 2009;15(10):CR511-CR517

11 Manca Bitti ML, Saccucci P, Bottini E, Gloria-Bottini F. p53 codon 72 polymorphism and type 1 diabetes mellitus. J Pediatr Endocrinol Metab 2010;23(03):291-292

12 Bottini N, Musumeci L, Alonso A, et al. A functional variant of lymphoid tyrosine phosphatase is associated with type I diabetes. Nat Genet 2004;36(04):337-338

13 Spencer N, Hopkinson DA, Harris H. Quantitative differences and gene dosage in the human red cell acid phosphatase polymorphism. Nature 1964;201:299-300

14 Bottini N, Bottini E, Gloria-Bottini F, Mustelin T. Low-molecularweight protein tyrosine phosphatase and human disease: in search of biochemical mechanisms. Arch Immunol Ther Exp (Warsz) 2002;50(02):95-104

15 Bottini N, Stefanini L, Williams S, et al. Activation of ZAP-70 through specific dephosphorylation at the inhibitory Tyr-292 by the low molecular weight phosphotyrosine phosphatase (LMPTP). J Biol Chem 2002;277(27):24220-24224

16 Matlashewski GJ, Tuck S, Pim D, Lamb P, Schneider J, Crawford LV. Primary structure polymorphism at amino acid residue 72 of human p53. Mol Cell Biol 1987;7(02):961-963

17 Zheng SJ, Lamhamedi-Cherradi SE, Wang P, Xu L, Chen YH. Tumor suppressor p53 inhibits autoimmune inflammation and macrophage function. Diabetes 2005;54(05):1423-1428

18 Vang T, Congia M, Macis MD, et al. Autoimmune-associated lymphoid tyrosine phosphatase is a gain-of-function variant. Nat Genet 2005;37(12):1317-1319

19 Gloria-Bottini F, Ammendola M, Saccucci P, Pietropolli A, Magrini A, Bottini E. The association of PTPN22 polymorphism with endometriosis: effect of genetic and clinical factors. Eur J Obstet Gynecol Reprod Biol 2013;169(01):60-63 